Jurnal Indobiosains. Vol. 2 No. 1 Edisi Februari 2020

https://jurnal.univpgri-palembang.ac.id/index.php/biosains

\title{
RESPONS PERTUMBUHAN TANAMAN SAWI PAKCOY (Brassica chinensis L.) TERHADAP PEMBERIAN AIR KELAPA TUA (Cocos nucifera)
}

\author{
Lia Setyawati ${ }^{1}$, Marmaini ${ }^{2}$, Yunita Panca Putri $^{3}$ \\ ${ }^{1,2,3}$ Program Studi Biologi, Fakultas Matematika dan Ilmu Pengetahuan Alam \\ Universitas PGRI Palembang \\ Jl. Jendral A. Yani Lorong Gotong Royong 9/10 Ulu Palembang \\ *e-mail :liasetyawti015@gmail.com
}

\begin{abstract}
Pakcoy (Brassica chenensis L.) is a type of vegetable that belongs to the Brassicaceae family and is a short-lived plant. This research was conducted in April-May 2019. This study used a Completely Randomized Design consisting of 6 treatments and 4 replications. The purpose of this study was to determine the effect of the administration of old coconut water on the growth of pakcoy mustard plants and to find out at what dosage of coconut water can give the best results on mustard cabbage plants. The results showed that in plant height the lowest value was obtained in the treatment of P0 $4.0 \mathrm{~cm}$ and the highest value in the treatment of P5 with a value of $4.71 \mathrm{~cm}$. In the number of leaves obtained the lowest value in the P0 4.25 treatment strands and the highest value in the P5 treatment 4.62 strands. In the wet weight, the lowest value was obtained in the treatment of P0 0.15 grams and the highest value in the treatment of P5 0.18 grams. At the dry weight obtained the lowest value at P0 0.0625 gram treatment and the highest value at P5 0.0085 gram treatment.
\end{abstract}

Keywords: Mustard Pakcoy (Brassica chinensis L.), Old coconut water (Cocos nucifera L.), Complete Randomized Design (CRD), Wet weight, dry weight.

\begin{abstract}
ABSTRAK
Sawi Pakcoy (Brassica chenensis L.) merupakan tanaman jenis sayur-sayuran yang termasuk keluarga Brassicaceae dan termasuk tanaman berumur pendek. Penelitian ini dilakukan pada bulan April-Mei 2019. Penelitian ini menggunakan Rancangan Acak Lengkap yang terdiri dari 6 perlakuan dan 4 ulangan. Adapun tujuan dari penelitian ini untuk mengetahui pengaruh pemberian air kelapa tua terhadap pertumbuhan tanaman sawi pakcoy dan untuk mengetahui pada dosis berapakan air kelapa dapat memberikan hasil terbaik pada tanaman sawi pakcoy. Hasil penelitian menunjukkan bahwa pada tinggi tanaman didapat nilai terendah pada perlakuan P0 4,0 cm dan nilai tertinggi pada perlakuan P5 dengan nilai 4,71 cm. Pada jumlah daun diperoleh nilai terendah pada Perlakuan P0 4,25 helai dan nilai tertinggi pada perlakuan P5 4,62 helai. Pada berat basah di peroleh nilai terendah pada perlakuan P0 0,15 gram dan nilai tertinggi pada perlakuan P5 0,18 gram. Pada berat kering diperoleh nilai terendah pada perlakuan P0 0,0625 gram dan nilai tertinggi pada perlakuan P5 0,0085 gram
\end{abstract}

Kata Kunci : Sawi Pakcoy (Brassica chinensis L.), Air kelapa tua (Cocos nucifera L.), Rancangan Acak Lengkap (RAL), Berat basah, Berat kering. 


\section{PENDAHULUAN}

Sayuran merupakan salah satu komoditas penting dalam mendukung ketahanan pangan nasional serta pemenuhan gizi masyarakat.Komoditas ini memiliki keragaman yang luas dan berperan sebagai sumber karbohidrat, protein nabati, vitamin, dan mineral yang bernilai ekonomi tinggi (Manure, 2014).

Pakcoy (Brassica chinensis L.) merupakan tanaman jenis sayur-sayuran yang termasuk keluarga Brassicaceae. Tumbuhan pakcoy masih memiliki kerabat dekat dengan sawi. Penampilannya sangat mirip dengan sawi, akan tetapi lebih pendek dan kompak, tangkai daunnya lebar dan kokoh, tulang daunnya mirip dengan sawi hijau, daun lebih tebal dari sawi hijau.

Pupuk organik cair merupakan salah satu jenis pupuk yang banyak beredar di pasaran. Selain dapat memperbaiki sifat fisik, kimia, dan biologi tanah,pupuk organik cair dapat membantu meningkatkan produksi tanaman, meningkatkan kualitas produk tanaman, mengurangi penggunaan pupuk anorganik dan dapat digunakan sebagai alternatif pengganti pupuk kandang (Parman, 2007).

Salah satu pupuk alami yang dapat meningkatkan pertumbuhan vegetative tanaman adalah air kelapa.Air kelapa merupakan cairan endosperm buah kelapa mengandung senyawa-senyawa biologi aktif.

Air kelapa mengandung komposisi kimia yang unik yang terdiri dari mineral, vitamin, gula, asam amino, dan fitohormon yang memiliki efek signifikan terhadap pertumbuhan tanaman (Wiranto, 2015). Senyawa organik tersebut diantaranya adalah auksin dan sitokinin.

Auksin berfungsi dalam menginduksi pemanjangan sel, mempengaruhi dominansi apical, penghambatan pucuk aksilar dan adventif serta inisiasi perakaran sedangkan sitokinin berfungsi untuk merangsang pembelahan sel dalam jaringan dan merangsang pertumbuhan tunas (Salisbury dan Ross, 1995).

Menurut Agampodi dan Jayawardena (2009), air kelapa yang digunakan dalam kulturjaringan dapat meningkatkan inisiasi kalus dan perkembangan akar. Berdasarkan analisis hormon ternyata dalam air kelapa mengandung hormone giberelin, sitokinin, dan auksin.

\section{BAHAN DAN METODE}

Penelitian dilaksanakan pada bulan April-Mei 2019 di Workshop Fakultas MIPA Universitas PGRI Palembang. Adapun alat yang digunakan dalam penelitian ini adalah polybag, timbangan, sekop, derigen, kertas label, camera hp, mistar, dan alat tulis . Sedangkan bahan yang digunakan adalah benih sawi pakcoy, tanah, air, dan air kelapa tua (Cocos nucifera L.).

Penelitian ini menggunakan Analisis Sidik Ragam dengan 6 perlakuan dan 4 ulangan dengan masing-masing konsentrasi :

1. $\mathrm{P}_{0}: \mathrm{kontrol} / \mathrm{tanpa}$ air kelapa

2. $\mathrm{P}_{1}: 100 \mathrm{ml}$ air kelapa

3. $\mathrm{P}_{2}: 150 \mathrm{ml}$ air kelapa

4. $\mathrm{P}_{3}: 200 \mathrm{ml}$ air kelapa

5. $\mathrm{P}_{4}: 250 \mathrm{ml}$ air kelapa

6. $\mathrm{P}_{5}: 300 \mathrm{ml}$ air kelapa

Parameter yang diamati dalam penelitian ini terdiri dari Tinggi Tanaman $(\mathrm{cm})$, Jumlah daun (helai), Berat Basah (gram) dan Berat Kering (gram). 


\section{HASIL DAN PEMBAHASAN}

\section{Tinggi Tanaman Sawi Pakcoy Setelah Pemberian Air Kelapa Tua.}

Diperoleh data tinggi tanaman pada perlakuan $\mathrm{P} 0$ menghasilkan nilai ratarata tinggi tanaman $4,06 \mathrm{~cm}$, pada perlakuan $\mathrm{P} 1$ diperoleh rata-rata tinggi tanaman $4,1 \mathrm{~cm}$, pada perlakuan $\mathrm{P} 2$ diperoleh rata-rata tinggi tanaman $4,56 \mathrm{~cm}$, pada perlakuan $\mathrm{P} 3$ diperoleh rata-rata tinggi tanaman $4,6 \mathrm{~cm}$, pada perlakuan $\mathrm{P} 4$ diperoleh rata-rata tinggi tanaman 4,65 cm, pada perlakuan P5 diperoleh rata-rata tinggi tanaman $4,71 \mathrm{~cm}$. Nilai rata-rata tinggi tanaman sawi pakcoy disajikan pada Tabel 1 berikut :

Tabel. 1. Nilai rata-rata tinggi tanaman sawi pakcoy

\begin{tabular}{lccccc}
\hline $\begin{array}{c}\text { Sumber } \\
\text { Ragam }\end{array}$ & $\begin{array}{c}\text { Derajat Bebas } \\
\text { (DB) }\end{array}$ & $\begin{array}{c}\text { Jumlah } \\
\text { Kuadrat }(\mathrm{JK})\end{array}$ & $\begin{array}{c}\text { Kuadrat } \\
\text { Tengah (KT) }\end{array}$ & F hitung & $\begin{array}{c}\text { Ftabel } \\
5 \%\end{array}$ \\
\hline Perlakuan & 5 & 3,32 & 0,66 & & \\
Galat & 18 & 6,45 & 0,35 & & \\
Jumlah & 23 & 9,77 & 1,01 & $1,88^{(\mathrm{tn})}$ & 2,77 \\
\hline
\end{tabular}

Adanya pengaruh terhadap tinggi tanaman diduga disebabkan konsentrasi yang diberikan ke tanaman tercukupi dalam proses pertumbuhan tanaman, dimana air kelapa mengandung ZPT berupa auksin, sitokinin dan gibrelin. Hal ini sesuai dengan pernyataan, Azwar (2008) air kelapa ternyata memiliki manfaat untuk meningkatkan pertumbuhan tanaman. Hasil penelitian menunjukan bahwa air kelapa kaya akan potassium (kalium) hingga 17 persen.Selain kaya mineral, air kelapa juga mengandung gula antara 1,7 sampai $2,6 \%$ dan protein 0,07 hingga $0,55 \%$. Mineral lainnya antara lain natrium $(\mathrm{Na})$, Kalsium $(\mathrm{Ca})$, magnesium $(\mathrm{Mg})$, ferum $(\mathrm{Fe})$, cuprum $(\mathrm{Cu})$, fosfor $(\mathrm{P})$, dan sulfur (S). Disamping kaya mineral air kelapa juga mengandung berbagai macam vitamin seperti asam sitrat, asam nikotinat, asam pantotenal, asam folat, niacin, riboflavin, dan thiamin. Terdapat 3 hormon alami yaitu auksin,giberelin, dan sitokinin sebagai pendukung pembelaha sel embrio kelapa.

\section{Jumlah Daun Tanaman Sawi Pakcoy Setelah Pemberian Air Kelapa Tua.}

Air kelapa mengandung beberapa jenis hormon.Widiastoety dan Purbadi (2003) menyatakan bahwa penambahan air kelapa dapat mendorong pertumbuhan panjang dan lebar daun serta panjang dan jumlah akar plantlet anggrek Dendrobium. Air memiliki fungsi yang vital bagi mahluk hidup, tidak terkecuali tanaman. Hal ini erat kaitannya sebagai bahan dasar yang akan digunakan pada proses fotosintesis yang merupakan proses fisiologi tanaman untuk pembentukan karbohidrat (Tjionger, 2009).

Jarak tanam berpengaruh terhadap pertumbuhan tinggi tanaman secara umum patani kita di Indonesia tidak terlalu memperhatikan jarak tanam yang sesuai dalam berbudidaya, oleh karenanya banyak sekali produksi petani yang kurang maksimal. Maka alternatif tepat yang dapat kita lakukan yaitu pengaturan populasi tanaman sebab pengaturan populasi tanaman pada hakekatnya adalah pengaturan jarak 
tanam untuk meminimalkan persaingan dalam penyerapan hara, air dan cahaya matahari, sehingga apabila tidak diatur dengan baik akan mempengaruhi hasil tanaman. Jarak tanam yang rapat mengakibatkan terjadi kompetisi intra spesies dan antar spesies.Beberapa penelitian tentang jarak tanam, menunjukan bahwa semakin rapat jarak tanam berpengaruh pada jumlah cabang serta luas daun (Budiastuti, 2000).

Diperoleh hasil terendah pada perlakuan P0 dengan rata-rata nilai jumlah daun 4,25 helai, sedangkan nilai rata-rata tertinggi pada perlakuan P5 4,62 helai. Nilai rata-rata jumlah daun tanaman sawi pakcoy disajikan dalam Tabel 2 berikut :

Tabel. 2. Nilai rata-rata jumlah daun tanaman sawi pakcoy

\begin{tabular}{cccccc}
\hline $\begin{array}{c}\text { Sumber } \\
\text { Ragam }\end{array}$ & $\begin{array}{c}\text { Derajat } \\
\text { Bebas (DB) }\end{array}$ & $\begin{array}{c}\text { Jumlah } \\
\text { Kuadrat (JK) }\end{array}$ & $\begin{array}{c}\text { Kuadrat } \\
\text { Tengah KT) }\end{array}$ & $\begin{array}{c}\text { F } \\
\text { Hitung }\end{array}$ & $\begin{array}{c}\text { F tabel } \\
5 \%\end{array}$ \\
\hline Perlakuan & 5 & 0,34 & 0,068 & & \\
Galat & 18 & 2,32 & 0,12 & & \\
Jumlah & 23 & 2,66 & 0,188 & $0,56^{(\mathrm{tn})}$ & 2,77 \\
\hline
\end{tabular}

\section{Berat Basah Tanaman Sawi Pakcoy Setelah Pemberian Air Kelapa Tua.}

Berat basah berkaitan dengan luas daun dan panjang akar. Berkurangnya luasdaun akan mempengaruhi fotosintesis sedangkan panjang akar akan mempengaruhi penyerapan air dan hara. Menurut Haryadi (2013), luas daun memegang peranan penting, karena laju fotosintesis berlangsung mengikuti dengan perkembangan luas daun. Fitter dan Hay (1994) menyatakan bahwa adanya cekaman garam menyebabkan akar tanaman berada dalam lingkungan dengan potensial air yang lebih rendah, sehingga penyerapan air menjadi terhambat.

Tabel. 3. Nilai rata-rata berat basah tanaman sawi pakcoy

\begin{tabular}{lcllll}
\hline $\begin{array}{l}\text { Sumber } \\
\text { Ragam }\end{array}$ & $\begin{array}{l}\text { Derajat } \\
\text { Bebas } \\
\text { (DB) }\end{array}$ & $\begin{array}{l}\text { Jumlah } \\
\text { Kuadrat } \\
\text { (JK) }\end{array}$ & $\begin{array}{l}\text { Kuadrat } \\
\text { Tinggi(KT) }\end{array}$ & F hitung & $\begin{array}{c}\text { Ftable } \\
\mathbf{5 \%}\end{array}$ \\
\hline Perlakuan & 5 & 0,008 & 0,0016 & & \\
Galat & 18 & 0,002 & 1,111 & & \\
Jumlah & 23 & 0,01 & $\mathbb{1}, 1126$ & $1.440_{\text {(m) }}^{\text {(t) }}$ & 2,77 \\
\hline
\end{tabular}

Tabel 3 menunjukkan bahwa pemberian nutrisi air kelapa pada setiap perlakuan mulai dari perlakuan P0 (kontrol), P1 (100 ml), P2 (150 ml), P3 (200 ml), P4 $(250 \mathrm{ml})$, P5 $(300 \mathrm{ml})$ diperoleh hasil terendah P0 kontrol tanpa air kelapa dengan nilai rata-rata berat basah 0,15 gram, sedangkan nilai tertinggi pada perlakaun P5 pada dosis $300 \mathrm{ml}$ air kelapa dengan nilai rata-rata berat basah 0,18 gram.

\section{Berat Kering Tanaman Sawi Pakcoy Setelah Pemberian Air Kelapa Tua.}

Adanya ketidakseimbangan ion dalam tanah yang menyebabkan menurunnya kemampuan akar dalam menyerap air dapat menurunkan jumlah air dalam tanaman sehingga menyebabkan pengurangan nilai parameter berat kering. Gardner et al. (1991), menyatakan bahwa penurunan jumlah air akan menyebabkan penurunan kemampuan fotosintesis sehingga ketersedian karbohidrat 
sebagai sumber energi untuk pertumbuhan akan menurun. Menurunnya ion K+ akibat ketidakseimbangan ion pada akar karena perlakuan $\mathrm{NaCl}$ menyebabkan turgor sel akan menurun dan stomata akan menutup.

Fitter dan Hay (1994), menyatakan bahwa menutupnya stomata pada daun akan mengurangi asupan $\mathrm{CO} 2$ ke sel-sel mesofil sehingga fotosintesis terhambat dan fotositant yang terbentuk sedikit. Berdasarkan Tabel 4, Menunjukkan bahwa pemberian air kelapa pada setiap perlakuan diperoleh hasil terendah P0 kontrol tanpa air kelapa dengan nilai rata-rata berat kering 0,0625 gram. Sedangkan nilai tertinggi didapat pada perlakuan P5 dengan dosis 300 $\mathrm{ml}$ air kelapa dengan nilai rata-rata 0,085 gram.

Tabel. 4. Nilai rata-rata berat kering tanaman sawi pakcoy

\begin{tabular}{|c|c|c|c|c|c|c|}
\hline \multirow[t]{2}{*}{ Sumber Ragam } & \multicolumn{2}{|c|}{ Derajat Bebas } & \multirow[t]{2}{*}{ Jumlah Kuadrat (JK) } & \multirow[t]{2}{*}{ Kuadrat Tinggi (KI) } & \multirow[t]{2}{*}{ F hitung } & Ftable \\
\hline & & & & & & \\
\hline Perla & & & 0,0 & 0,00003 & & \\
\hline $\mathrm{G}$ & 1 & 8 & 0 , & 0,0007 & & \\
\hline $\mathrm{Jumlah}$ & 2 & 3 & 0,0143 & $\begin{array}{lllll}0 & 0 & 0 & 1\end{array}$ & $0,4285^{(\mathrm{tn})}$ & 2,77 \\
\hline
\end{tabular}

Berdasarkan hasil Analisis Sidik Ragam (ANSIRA) pada tabel diperoleh nilai Fhitung lebih kecil dari Ftabel pada taraf 5\%. Hal ini menunjukan bahwa pemberian air kelapa pada berbagai perlakuan berpengaruh tidak nyata terhadap pertumbuhan berat kering tanaman sawi pakcoy.

\section{KESIMPULAN}

Dari hasil penelitian yang telah dilakukan selama 45 hari terhadap Respons Pertumbuhan Tanaman Sawi Pakcoy (Brassica chinensisL.) Terhadap Pemberian Air Kelapa Tua (Cocos nucifera L.) dapat di simpulkan bahwa pemberian air kelapa memberikan pengaruh tidak nyata pada setiap perlakuan dan dosis terbaik yang diberikan untuk tanaman sawi pakcoy adalah pada perlakuan P5 dengan dosis $300 \mathrm{ml}$ air kelapa.

\section{DAFTAR PUSTAKA}

Agampodi, V. A. dan Jayawardena, B. 2009.Effect of Cooconut (Coconut nucifera L.) Water Extracts on Adventitious Root Development in Vegetative
Propagation of Draceana purplecompacta L. Acta physiol. Plant, 31 : 279-284.

Azwar .2008. Air Kelapa Pemacu Pertumbuhan anggrek.Http://www. azwar. web. ugm. ac.id. Akses 3 juli 2019.

Budiastuti, 2000 . Pengaruh Triakontanol dan Jarak Tanaman Pada Tanaman Kacang Hijau (Phaseolus radiates L.) Agrosain Vol 2 (2) (2000). Universitas 11 Maret, Surakarta.

Fitter. AH \& Hay. RKM, 1994, Fisiologi LingkunganTanaman, Gadjah Mada University Press, Yogyakarta.

Gardner. PF, Pearce. RB \& Mitchel, RL, 1991,Fisiologi Tanaman Budidaya, UI Press, Jakarta

Haryadi. 2013. Pengukuran Luas Daun Dengan MetodeSimpson. Anterior. 12(2): $1-5$. 
Manure. 2014. Pertumbuhan Dan Produksi Tanaman Sawi (Brassica Juncea L) Dengan Pemberian Mikroorganisme Lokal (Mol) Dan Pupuk Kandang Ayam.Jurnal Agrisistem 10 (1): 1858-4330.

Parman, Sarjana.2007. Pengaruh Pemberian Pupuk Organik Cair terhadap Tertumbuhan dan Produksi Kentang (Solanum tuberosum L.).Buletin Anatomi dan Fisiologi 15(2): 65-73.

Salisbury, F. B dan Ross, C. W, 1995.Fisiologi Tumbuhan jilid 2 \& 3. ITB. Bandung.

Tjionger, Menas. 2009. Esensialitas Air Bagi Pertumbuhan dan Produksi Tanaman Jagung.

http://www.tanindo.com/abdi15/hal1801.

Diakses tanggal 27 Juni 2019 pukul 22:46 WIB

Widiastoety, D. dan Purbadi. 2003. Pengaruh Bubur Ubi Kayu Terhadap Pertumbuhan Plantlet Anggrek Dendrobium J.Hort. 13 (1):1-6.

Wiranto,B. 2015. Use of Coconut Water and Firtilizer for In Vitro Proliferation and Plantiet Production of Dendrobium 'Gradita 3'. In Vitro Cell Development Biology Jurnal. 